ENTITA : Jurnal Pendidikan Ilmu Pengetahuan Sosial dan Ilmu-Ilmu Sosial http://ejournal.stainpamekasan.ac.id/index.php/entita

P-ISSN:2715-7555 E-ISSN:2716-1226

\title{
Peningkatan Prestasi Belajar Melalui Strategi Pembelajaran Kooperatif Tipe Team Assisted Individualization (TAI) Mata pelajaran IPS siswa kelas III SDN Kalianget Barat II Kab. Sumenep
}

\author{
Tri Sutrisno \\ IAIN Madura \\ trisutrisno@iainmadura.ac.id
}

\begin{abstract}
This research aims to; Want to know an increase in social studies learning achievement after the implementation of cooperative learning model Teams Assisted Individualization class III students of SDN Kalianget Barat II Kab. Sumenep "; Want to know the effect of motivation to study social studies after the implementation of cooperative learning model Teams Assisted Individualization class III students SDN Kalianget Barat II Kab. Sumenep ", provides an overview of appropriate learning methods in an effort to improve student achievement and make students become active in teaching and learning activities. In this study using a class action research design (CAR). The design of the classroom action research was chosen because (1) the study of classroom context research was carried out by the teacher to solve social studies learning problems, because the third grade students of SDN Kalianget Barat II Sumenep Regency still experiencing difficulties in achievement especially social studies subjects, has not found the right learning strategy. Based on the results of the research that has been presented for three cycles, the results of the entire discussion and analysis that have been carried out can be concluded as follows; The TAI model of cooperative learning methods can improve the quality of social studies learning; The TAl model of cooperative learning method has a positive impact in increasing student achievement which is marked by an increase in student learning completeness in each cycle, namely cycle I (68.42\%), cycle II (81.58\%), cycle III (94.74\%).
\end{abstract}

Keywords: Achievement, cooperative learning, Teams Assisted Individualization

Penelitian ini bertujuan untuk; Ingin mengetahui peningkatan prestasi belajar IPS setelah diterapkannya pembelajaran kooperatif model Teams Assisted Individualization siswa kelas III SDN Kalianget Barat II Kab. Sumenep" ; Ingin mengetahui pengaruh motivasi belajar IPS setelah diterapkannya pembelajaran kooperatif model Teams Assisted Individualization siswa kelas III SDN Kalianget Barat II Kab. Sumenep", Memberikan gambaran tentang metode pembelajaran yang tepat dalam upaya meningkatkan prestasi belajar siswa dan menjadikan siswa menjadi aktif dalam kegiatan belajar mengajar. Dalam penelitian ini menggunakan rancangan penelitian tindakan kelas (PTK). Rancangan penelitian tindakan kelas dipilih karena (1) penelitian pembelajaran yang berkonteks kelas yang dilaksanakan oleh guru untuk memecahkan masalah-masalah pembelajaran IPS, karena siswa kelas III SDN Kalianget Barat II Kab. Sumenep masih mengalami kesulitan dalam prestasi khususnya mata pelajaran IPS, belum menemukan strategi pembelajaran yang tepat. Berdasarkan hasil penelitian yang telah dipaparkan selama tiga siklus, hasil seluruh pembahasan serta analisis yang telah dilakukan dapat disimpulkan sebagai berikut; Metode pembelajaran kooperatif model TAI dapat meningkatkan kualitas pembelajaran IPS; Metode pembelajaran kooperatif model TAI 
memiliki dampak positif dalam meningkatkan prestsi belajar siswa yang ditandai dengan peningkatan ketuntasan belajar siswa dalam setiap siklus, yaitu siklus I $(68,42 \%)$, siklus II (81,58\%), siklus III (94,74\%).

Kata Kunci: Pretasi, Kooperatif, Teams Assisted Individualization

Received : 3 Maret 2020; Revised: 13 Desember 2020; Accepted: 17 Desember 2020

(c) ENTITA : Jurnal Pendidikan IImu

Pengetahuan Sosial dan IImu-IImu Sosial http://doi.org/10.19105/ejpis

Institut Agama Islam Negeri Madura, Indonesia

\section{Pendahuluan}

Sebagai fasilitor yang berusaha mencipatakan kondisi belajar mengajar yang efektif, sehingga memungkinkan proses belajar mengajar, mengembangkan bahan pelajaran Guru memiliki peranan yang sangat penting dalam menentukan kuantitas dan kualitas pengajaran yang dilaksanakan. Oleh sebab itu, guru harus memikirkan dan membuat perencanaan secaraa seksama dalam meningkatkan kesempatan belajar bagi siswanya dan memperbaiki kualitas mengajarnya.

Hal ini menuntut perubahan-perubahan dalam mengorganisasikan kelas, penggunaan metode mengajar, strategi belajar mengajar, maupun sikap dan karakteristik guru dalam mengelola proses belajar mengajar. Guru berperan sebagai pengelola proses belajar-mengajar, bertindak dengan baik, dan meningkatkan kemampuan siswa untuk menyimak pelajaran dan menguasai tujuan-tujuan pendidikan yang harus mereka capai. Untuk memenuhi hal tersebut di atas, guru dituntut mampu mengelola proses belajar mengajar yang memberikan rangsangan kepada siswa, sehingga ia mau belajar karena siswalah subyek utama dalam belajar.

Mengajar adalah membimbing belajar siswa sehingga ia mampu belajar. Dengan demikian aktifitas siswa sangat diperlukan dalam kegiatan belajar-mengajar sehingga siswalah yang seharusnya banyak aktif, sebab siswa sebagai subyek didik adalah yang merencanakan, dan ia sendiri yang melaksanakan belajar. Pada kenyataan, di sekolahsekolah seringkali guru yang aktif, sehingga siswa tidak diberi kesempatan untuk aktif.

Kegiatan belajar bersama dapat membantu memacu belajar aktif. Kegiatan belajar dan mengajar di kelas memang dapat menstimulasi belajar aktif. Namun kemampuan untuk mengajar melalui kegiatan kerjasana kelompok kecil akan memungkinkan untuk menggalakkan kegiatan belajar aktif dengan cara khusus. Apa yang didiskusikan siswa dengan teman-temannya dan apa yang diajarkan siswa kepada teman-temannya 
Peningkatan Prestasi Belajar Melalui Strategi Pembelajaran Kooperatif Tipe

Team Assisted Individualization (TAI) Mata pelajaran IPS siswa kelas III SDN

Kalianget Barat II Kab. Sumenep

memungkinkan mereka untuk memperoleh pemahaman dan penguasaan materi pelajaran.

Pembelajaran IPS tidak lagi mengutamakan pada penyerapan melalui pencapaian informasi, tetapi lebih mengutamakan pada pengembangan kemampuan dan pemrosesan informasi. Untuk itu aktifitas peserta didik perlu ditingkatkan melalui latihan-latihan atau tugas dengan bekerja dalam kelompok kecil dan menjelaskan ide-ide kepada orang lain. (Hartoyo, 2000:24).

Langkah-langkah tersebut memerlukan partisipasi aktif dari siswa. Untuk itu perlu ada metode pembelajaran yang melibatkan siswa secaraa langsung dalam pembelajaran. Adapun metode yang dimaksud adalah metode pembelajaran kooperatif. Pembelajaran kooperatif adalah suatu pengajaran yang melibatkan siswa bekerja dalam kelompokkelompok untuk menetapkan tujuan bersama. (Felder, 1994:2).

Pembelajaran kooperatif lebih menekankan interaksi antar siswa. Dari sini siswa akan melakukan komunikasi aktif dengan sesama temannya. Dengan komunikasi tersebut diharapkan siswa dapat menguasai materi pelajaran dengan mudah karena "siswa lebih mudah memahami penjelasan dari kawannya dibanding penjelasan dari guru, karena taraf pengetahuan serta pemikiran mereka lebih sejalan dan sepadan". (Sulaiman dalam Wahyuni 2001: 2).

Model kooperatif tipe Teams Assisted Individualization dirancang untuk menggabungkan insentif motivasional dari penghargaan kelompok dengan program pembelajaran individual yang cocok dengan tingkatan yang dimiliki oleh siswa.

Siswa dikelompokkan kedalam empat atau lima orang secara heterogen. Setiap siswa mengerjakan unit-unit program ilmu penetahuan sosial sesuai dengan kemampuan masing-masing. Artinya, dalam suatu tim bisa saja si A mngerjakan unit 2, si $B$ mengerjakan unit 5. Para siswa mengikuti rangkaian kegiatan yang teratur, mulai dari membaca lembar pembelajaran, mengerjakan lembar kerja, memeriksa apakah dia telah menguasai keterampilan dan mengikuti tes.

Anggota tim bekerja secara berpasangan, saling bertukar lembar jawaban dan memeriksa pekerjaan temannya. Jika seorang siswa berhasil mencapai atau melampaui skor 80, dia mengikuti final tes. Anggota tim bertanggung jawab meyakinkan bahwa temannya telah siap mengikuti final tes. Baik tanggungjawab individual dan penghargaan kelompok ada di dalam metode pembelajaran ini. 
Setiap minggu guru menjumlahkan banyaknya unit yang telah diselesaikan oleh semua anggota tim dan memberikan sertifikat atau penghargaan lainnya kepada tim yang memenuhi kriteria berdasarkan jumlah final tes yang berhasil dilampaui.

Berasarkan paparan tersebut di atas, maka peneliti ingin mencoba melakukan penelitian dengan judul "Peningkatan Prestasi Belajar Melalui Strategi Pembelajaran Kooperatif Tipe Team Assisted Individualization (TAI) Mata Pelajaran IPS Siswa Kelas III SDN Kalianget Barat II Kab. Sumenep.

\section{Metode Penelitian}

Dalam penelitian ini menggunakan rancangan penelitian tindakan kelas (PTK). Rancangan penelitian tindakan kelas dipilih karena (1) penelitin pembelajaran yang berkonteks kelas yang dilaksanakan oleh guru untuk memecahkan masalah-masalah pembelajaran IPS, karena siswa kelas III SDN Kalianget Barat II Kab. Sumenep masih mengalami kesulitan dalam prestasi khususnya mata pelajaran IPS, belum menemukan strategi pembelajaran yang tepat, (2) penelitian dilakukan untuk mengubah keadaan, kenyataan, karena pembelajaran IPS di kelas III SDN Kalianget Barat II Kab. Sumenep rata-rata kelas masih di bawah $40 \%$ dan diharapkan setelah diadakan penelitian ini maka rata-rata kelas menjadi $75 \%$ atau lebih, (3) penelitian dilakukan pada konteks alamiah, dengan maksud untuk mengkaji permasalahan pembelajaran IPS yang dialamai oleh siswa kelas III SDN Kalianget Barat II Kab. Sumenep, dan (4) dalam pelaksanaannya, penelitian ini dilakukan secara kolaboratif selama penelitian berlangsung.

Proses pelaksanaan penelitian tindakan kelas in merujuk pada pendapat Kemmis dan Taggrart (dalam Wiriaatmadja, 2005:66-67) yang menjelaskan tahap-tahap penelitian yang dimuli dari (1) menyusun perencanaan (plan), (2) melaksanakan tindakan (act), (3) pengamatan (observe), dan (4) refleksi (reflect). Dengan demikian penelitian tindakan merupakan suatu proses yang memilki siklus yang bersiat spiral, mulai dari perencanaan, melakuan tindakan, dan penemuan fakta-fakta untuk melakukan refleksi.

Penelitian ini mengacu pada perbaikan pembelajaran yang berkesinambungan. Kemmis dan Taggart (1988:14) menyatakan bahwa model penelitian tindakan adalah berbentuk spiral. Tahapan penelitian tindakan pada suatu siklus meliputi perencanaan atau pelaksanaan observasi dan refreksi. Siklus ini berlanjut dan akan dihentikan jika sesuai dengan kebutuhan dan dirasa sudah cukup. 
Penelitian ini dilakukan di SDN Kalianget Barat II Kab. Sumenep. Sekolah ini merupakan SD yang berada di dusun Asem nonggal Kecamatan Kalianget. Sekolah dijadikan tempat sebagai tempat penelitian didasarkan pada pertimbangan: (1) sekolah merupakan SD yang dekat dengan peneliti, (2) siswa mengalami kesulitan dalam mengikuti pembelajaran IPS, sehingga perlu diadakan tindakan kelas sebagai upaya pemecahan kesulitan siswa tersebut, dan (3) penelitian tentang IPS di sekolah ini belum pernah dilaksanakan sehingga hasil penelitian diharapkan dapat memberikan manfaat yang berharga bagi peningkatan pembelajaran IPS di sekolah tesebut.

Penelitian ini yang dijadikan subjek penelitian adalah siswa kelas III SDN Kalianget Barat II Kab. Sumenep tentang Peningkatan prestasi pelajar mata pelajaran IPS dengan menerapkan Metode Pembelajaran Kooperatif Model Teams Achievement Assisted Individualization Siswa kelas III, dengan jumlah siswa 38 (20 laki-laki dan 18 perempuan). Sedangkan jumlah guru, berjumlah 10 guru dengan rincian : 6 orang guru umum PNS, 1 orang kepala sekolah, 1 orang guru pendidikan jasmani dan kesehatan, 1 orang guru pendidikan agama Islam, Pendidikan guru, S.1, 100\% Dan guru telah banyak mengikuti penataran yaitu $69 \%$

Penelitian tindakan kelas ini dikenakan pada seluruh siswa dikenai tindakan karena penelitian tindakan kelas merupakan penelitian yang mengikuti alur pembelajaran yang sesungguhnya. Pertimbangan siswa kelas III sebagai subjek penelitian dikarenakan kelas III mengalami permasalahan Pembelajaran IPS

Dalam rangka menyusun dan mengelola data yang terkumpul sehingga dapat menghasilkan suatu kesimpulan yang dapat dipertanggung jawabkan maka digunakan analisis data kuantitatif dan pada metode observasi digunakan data kuantitatif. Cara perhitungan untuk mengetahui ketuntasan belajar siswa dalam proses belajar mengajar sebagai berikut:

1. Merekapitulasi hasil tes

2. Menghitung jumlah skor yang tercapai dan prosentasenya untuk masing-masiong siswa dengan menggunakan rumus ketuntasan belajar seperti yang terdapat dalam buku petunjuk teknis penilaian yaitu siswa dikatakan tuntas secara individual jika mendapatkan nilai minimal 65, sedangkan secara individual mencapai $85 \%$ yang telah memcapai daya serap lebih dari sama dengan $65 \%$.

3. Menganalisis hasil observasi yang dilakukan oleh teman sejawat pada Aktivitas guru dan siswa selama kegiatan belajar mengajar 
Tri Sutrisno

berlangsung.

Alat pengumpul data dalam penelitian ini adalah tes buatan guru yang fungsinya adalah: (1) Untuk menentukan seberapa baik siswa telah menguasai bahan pelajaran yang telah diberikan dalam waktu tertentu;(2) Untuk menentukan apakah suatu tujuan telah tercapai; dan (3) Untuk memperoleh suatu nilai (Arikunto, Suharismi, 2002: 19). Sedangkan tujuan dari tes adalah untuk mengetahui ketuntasan belajar siswa secaraa individual maupun secaraa klasikal. Disamping itu untuk mengetahui letak kesalahankesalahan yang dilakukan siswa sehingga dapat dilihat dimana kelemahannya, khususnya pada bagian mana Kompetensi dasar yang belum tercapai. Untuk memperkuat data yang dikumpulkan, maka juga digunakan metode observasi (pengamatan) yang dilakukan oleh teman sejawat untuk mengetahui dan merekam aktifitas guru dan siswa dalam proses belajar mengajar.

Untuk mengetahui kefektivan suatu metode dalam kegiatan pembelajaran perlu diadakan analisis data. Pada penelitian ini menggunakan teknik analisis dekriptif kualitatif, yaitu suatu metode penelitian yang bersifat menggambarkan kenyataan atau fakta sesuai dengan data yang diperoleh dengan tujuan untuk mengetahui prestasi belajar yang dicapai siswa, juga untuk memperoleh respon siswa terhadap kegiatan pembelajaran serta aktivitas siswa selama proses pembelajaran.

Untuk menganalisi tingkat keberhasilan atau presentase keberhasilan siswa setelah proses belajar mengajar setiap putarannya dilakukan dengan cara memberikan evaluasi berupa soal tes tertulis paa setiap akhir putaran.

Analisi ini dihitung dengan menggunakan statistik sederhana yaitu :

1. Untuk menilai ulangan atau tes formatif

Peneliti melakukan penjumlahan nilai yang diperoleh siswa, yang selanjutnya dibagi dengan jumlah siswa yang ada di kelas tersebut sehingga diperoleh rata-rata tes formatif dapat dirumuskan :

$$
\overline{\mathrm{X}}=\frac{\Sigma x}{\Sigma \mathrm{N}}
$$

Dengan $\quad \begin{aligned}: \bar{X} & =\text { Nilai rata-rata } \\ \Sigma X & =\text { Jumla semua nilai siswa } \\ \Sigma N & =\text { Jumlah siswa }\end{aligned}$


2. Untuk ketuntasan belajar

Ada dua kategori ketuntasan belajar yaitu secaraa perorangan dan secaraa klasikal. Berdasarkan petunjuk pelaksanaan belajar mengajar kurikulum 1994 (Depdikbud, 1994), yaitu seorang siswa telah tuntas belajar bila telah mencapai skor $65 \%$ atau nilai 65 , dan kelas disebut tuntas belajar baik dikelas tersebut terdapat $85 \%$ yang telah mencapai daya serap lebih dari atau sama dengan $65 \%$. Untuk menghitung presentase ketuntasan belajar digunakan rumus sebagai berikut

$$
\mathrm{P}=\frac{\sum \text { Siswa.yang.tuntas.belajar }}{\Sigma \text { Siswa }} \times 100 \%
$$

3. Untuk lembar observasi

a. Lembar observasi pengelola metode pembelajarn koooperatif model TAI.

b. Lembar observasi aktifitas guru dan siswa

\section{Hasil Penelitian}

Data penelitian diperoleh dari data observasi berupa pengamatan perngelolaan metode pembelajaran kooperatif model Team Assisted Individualization dan pengamatan aktivitas guru dan siswa pada setiap siklus.

Data lembar observasi diambil dari dua pengamatan yaitu data pengamatan pengelolaan metode pembelajaran kooperatif model Team Assisted Individualization yang digunakan untuk mengetahui pengaruh penerapan metode pembelajaran kooperatif model Team Assisted Individualization dalam meningkatkanprestasi belajar siswa dan data pengamatan aktivitas guru dan siswa.

Data tes formatif untuk mengetahui peneingkatan prestasi belajar siswa setelah diterapkannya metode pembelajaran kooperatif model Team Assisted Individualization.
A. Analisis Hasil Penelitian Siklus I
1. Tahap Perencanaan

Pada tahap ini peneliti mempersiapkan perangkat pembelajaran yang terdiri dari rencana pelajaran, sial tes formatif I dan alat-alat pengajaran yang mendukung. Selain itu juga dipersiapkan lembar observasi pengolahan metode pembelajaran kooperatif model Team Assisted Individualization, dan lembar observasi aktifitas guru dan siswa. 
2. Tahap kegiatan dan pelaksanaan

Pelaksanaan kegiatan belajar mengajar untuk siklus I dilaksanakan pada tanggal 12 Pebruari 2018 di Kelas III dengan jumlah siswa 38 siswa. Pelaksanaan metode pembelajaran kooperatif model Team Assisted Individualization melalui tahapan sebagai berikut : (1) Pelaksanaan pembelajaran, (2) Diskusi kelompok, (3) Tes, (4) Penghargaan kelompok, (5) Menentukan nilai individual dan kelompok. Dalam hal ini peneliti bertindak sebagai pengajar, sedangkan yang bertindak sebagai pengamat adalah seorang guru IPS Kelas III SDN Kalianget Barat II Kab. Sumenep. Adapun proses belajar mengajar mengacu pada rencana pelajaran yang telah dipersiapkan. Pengamatan (observasi) dilaksanakan bersamaan dengan pelaksanaan dengan pelaksanaan belajar mengajar.

Pada akhir proses belajar mengjaar siswa diberi tes formatif I dengan tujuan untuk mengetahui tingkat keberhasilan siswa dalam proses belajar mengajar yang telah dilakukan. Adapun data hasil penelitian pada siklus I adalah sebagi berikut

\section{Tabel 1 Pengelolaan Pembelajaran Pada Siklus I}

\begin{tabular}{|c|c|c|}
\hline NO & Aspek yang diamati & Nilai \\
\hline & Pengamatan KBM & \\
\hline & A Pendahuluan & 2 \\
\hline & 1. Memotivasi siswa & 2 \\
\hline 1 & 2. Menyampaikan tujuan pembelajaran & \\
\hline 1 & $\begin{array}{l}\text { 3. Menghubungkan dengan pelajaran } \\
\text { sebelumnya }\end{array}$ & 2 \\
\hline & $\begin{array}{l}\text { 4. Mengatur siswa dalam kelompok- } \\
\text { kelompok belajar }\end{array}$ & 2 \\
\hline & B. Kegiatan inti & \\
\hline & 5. Mempresentasikan langkah-langkah & 3 \\
\hline & $\begin{array}{l}\text { metode pembelajaran kooperatif } \\
\end{array}$ & 3 \\
\hline 2 & 7. Melatih keterampilan kooperatif & 3 \\
\hline & $\begin{array}{l}\text { 8. Mengawasi setiap kelompok secara } \\
\text { bergiliran }\end{array}$ & 3 \\
\hline & $\begin{array}{l}\text { 9. Memberikan bantuan kepada kelompok } \\
\text { yang mengalami kesulitan } \\
\text { C Penutup }\end{array}$ & 3 \\
\hline 3 & 1. Membimbing siswa membuat rangkuman & 3 \\
\hline & 2. Memberikan evaluasi & 3 \\
\hline 4 & Pengelolaan Waktu & 2 \\
\hline & Antusiasme Kelas & \\
\hline 5 & 1. Siswa antusias & 2 \\
\hline & 2. Guru antisias & 3 \\
\hline & & 32 \\
\hline Juml & & \\
\hline
\end{tabular}

Berdasarkan tabel di atas aspek-aspek yang mendapatkan kriteria kurang baik adalah memotivasi siswa, menyampaikan tujuan pembelajran, pengelolaan waktu, dan siswa 278 
antusias. Keempat aspek yang mendapat nilai kurang baik di atas, merupakan suatu kelemahan yang terjadi pada siklus I dan akan dijadikan bahan kajian untuk refleksi dan revisi yang akan dilakukan pada siklus II.

Berdasarkan hasilobservasi tampak bahwa aktivitas guru yang paling dominan pada siklus I adalah membimbing dan mengamati siswa dalam menemukan konsep, yaitu $21,7 \%$. Aktivitas lain yang presentasinya cukup besar adalah memberi umpan balik/ evaluasi, tanya jawab dan menjelaskan materi yang sulit yaitu masing-masing sebesar 13,3 \%. Sedangkan aktivitas siswa yang paling dominan adalah mengerjakan/ memperhatikan penjelasan guru yaitu 22,5\%. Aktivitas lain yang presentasinya cukup besar adalah bekerja dengan sesama anggota kelompok, diskusi antara siswa/ antara siswa dengan guru, dan membaca buku yaitu masing-masing 18,7 \% 14,4 dan 11,5 \%.

Pada siklus I, secaraa garis besar kegiatan belajar mengajar dengan metode pembelajaran kooperatif model TAI sudah dilaksanakan dengan baik, walaupun peran guru masih cukup dominanuntuk memberikan penjelasan dan arahan, karena model tersebut masih dirasakan baru oleh siswa.

Berikutnya dalah rekapitulasi hasil tes formatif siswa seperti terlihat pada tabel berikut.

Tabel 2 Rekapitulasi Hasil Tes Formatif Siswa Pada Siklus I

\begin{tabular}{lll}
\hline No & Uraian & Hasil Siklus I \\
1 & Nilai rata-rata tes formatif & 6,79 \\
2 & Jumlah siswa yang tuntas belajar & 26 \\
3 & Presentase ketuntasan belajar & 68,2 \\
\hline
\end{tabular}

Dari tabel di atas dapat dijelaskan bahawa dengan menerapkan metode pembelajaran kooperatif model TAI diperoleh nilai rata-rata prestasi belajar siswa adalah 6,79 dan ketuntasan belajar mencapai $68,42 \%$ atau ada 26 siswa dari 38 siswa sudah tuntas belajar. Hasil tersebut menunjukkan bahawa paa siklus pertama secaraa klasikal siswa belum tuntas belajar, karena siswa yang memperoleh nilai $\geq 65$ hanya sebesar $68,42 \%$ lebih kecil dari presentase ketuntasan yangt dikehendaki yaitu sebesar $85 \%$. Hal ini disebabkan akrena siswa masih merasa baru dan belum mengerti apa yang dimaksudkan dan digunakan guru dengan menerapkan metode pembelajaran kooperatif model TAI. 


\section{Refleksi}

Dalam pelaksanaan kegiatan belajar mengajar diperoleh informasi dari hasil pengamatan sebagai berikut :

1) Guru kurang maksimal dalam memotivasi siswa dan dalam menyampaikan tujuan pembelajaran.

2) Guru kurang bm,aksimal dalampengelolaan waktu

3) Siswa kurang aktif selama pembelajaran berlangsung

B. Analisis Hasil Penelitian Siklus II

1. Tahap perencanaan

Pada tahap ini peneliti mempersiapkan perangkat pembelajaran yang terdiri ari rencana pelajaran 2 , soal tes formatif 2 dan alat-alat pengajaran yang mendukung. Selain itu juga dipersiapkan lembar observasi pengelolaan metode pembelajaran kooperatif model TAI dan lembar observasi guru dan siswa.

2. Tahap kegiatan dan pelaksanaan

Pelaksanaan kegiatan belajar mengajar untuk siklus II dilaksanakan pada tanggal 19 Pebruari 2018 di Kelas III dengan jumlah siswa 38 siswa. Pelaksanan metode pembelajaran kooperatif model TAI melalui tahapan sebagai berikut; (1) Pelaksanaan pembelajran, (2) Diskusi kelompok, (3) Tes, (4) Penghargaan kelompok, (5) Menentukan nilai individual dan kelompok. Dalam hal ini peneliti bertindak sebagai pengajar, sedangkan yang bertindak sebagi pengamat adalah seorang guru Kelas III. Adapun proses belajar mengajar mengacu perencana pelajaran dengan memperhatikan revisi pada siklus I, sehingga kesalahan atau kekurangan pada siklus I tidak terulang lagi pada siklus II. Pengamatan (observasi) dilaksanakanbersamaan dengan pelaksanaan belajar mengajar.

Pada akhir proses belajar mengajar siswa diberi tes formatif II dengan tujuan untuk mengetahui tingkat keberhasilan siswa dalam proses belajar mengajar yang telah dilakukan. Instrument yang digunakan adalah tes formatif II. Adapun data hasil penelitian pada siklus II adalah sebagi berikut : 


\section{Tabel 3 Pengelolaan Pembelajaran Pada Siklus II}

\begin{tabular}{|c|c|c|}
\hline NO & Aspek yang diamati & Nilai \\
\hline & Pengamatan KBM & \\
\hline & $\begin{array}{l}\text { A Pendahuluan } \\
1 . \text { Memotivasi siswa }\end{array}$ & 3 \\
\hline & 2. Menyampaikan tujuan pembelajaran & 3,5 \\
\hline 1 & $\begin{array}{l}\text { 3. Menghubungkan dengan pelajaran } \\
\text { sebelumnya }\end{array}$ & 4 \\
\hline & $\begin{array}{l}\text { 4. Mengatur siswa dalam kelompok- } \\
\text { kelompok belajar }\end{array}$ & 4 \\
\hline & B. Kegiatan inti & \\
\hline & 1. Mempresentasikan langkah-langkah & 3,5 \\
\hline & metode pembelajaran kooperatif & 4 \\
\hline & 2. Membimbing siswa melakukan kegiatan & 4 \\
\hline & 3. Melatih keterampilan kooperatif & \\
\hline & $\begin{array}{l}\text { 4. Mengawasi setiap kelompok secara } \\
\text { bergiliran }\end{array}$ & 4 \\
\hline & $\begin{array}{l}\text { 5. Memberikan bantuan kepada kelompok } \\
\text { yang mengalami kesulitan }\end{array}$ & 3 \\
\hline & C Penutup & \\
\hline 3 & 1. Membimbing siswa membuat rangkuman & 3,5 \\
\hline & 2. Memberikan evaluasi & 4 \\
\hline 4 & Pengelolaan Waktu & 2 \\
\hline & Antusiasme Kelas & \\
\hline 5 & 1. Siswa antusias & 3,5 \\
\hline & 2. Guru antisias & 4 \\
\hline $\mathrm{Ju}$ & $\mathrm{ah}$ & 42 \\
\hline
\end{tabular}

Dari tabel di atas, tampak aspek-aspek yang diamati pada kegiatan belajar mengajar (siklus II) yang dilaksanakn oleh guru dengan menerapkan metode pembelajarn kooperatif model TAI mendapatkan penilaian yang cukup baik dari pengamat. Maksudnya dari seluruh penilaian tidak terdapat nilai kurang. Namun demikian penilaian tesebut belum merupakan hasil yang optimal, untuk itu ada beberapa aspek yang perlu mendapatkan perhatian untuk penyempurnaan penerapan pembelajaran selanjutnya. Aspek-aspek tersebut adalah memotivasi siswa, membimbing siswa merumuskan kesimpulan/ menemukan konsep, dan pengelolaan waktu.

Dengan penyempurnaan aspek-aspek I atas alam penerapan metode pembelajarn kooperatif model TAI diharapkan siswa dapat menyimpulkan apa yang telah mereka pelajari dan mengemukakan pendapatnya sehingga mereka akan lebih memahami tentang apa ynag telah mereka lakukan.

Berdasarkan hasil penelitian, tampak bahwa aktifitas guru yang paling dominan pada siklus II adalah membimbing dan mengamati siswa dalam menentukan konsep yaitu $25 \%$. Jika dibandingkan dengan siklus I, aktivitas ini mengalami peningkatan. Aktivitas guru yang mengalami penurunan adalah memberi umpan balik/evaluasi/ Tanya jawab 
(16,6\%), mnjelaskan materi yang sulit $(11,7)$. Meminta siswa mendiskusikan dan menyajikan hasil kegiatan (8,2\%), dan membimbing siswa merangkum pelajaran (6,7\%).

Sedangkan untuk aktivitas siswa yang paling dominan pada siklus II adalah bekerja dengan sesama anggota kelompok yaitu (21\%). Jika dibandingkan dengan siklus I, aktifitas ini mengalami peningkatan. Aktifitas siswa yang mengalami penurunan adalah mendengarkan/memperhatikan penjelasan guru (17,9\%). Diskusi antar siswa/ antara siswa dengan guru (13,8\%), menulis yang relevan dengan $\mathrm{KBM}(7,7 \%)$ dan merangkum pembelajaran (6,7\%). Adapun aktifitas siswa yang mengalami peningkatan adalah membaca buku (12,1\%), menyajikan hasil pembelajaran $(4,6 \%)$, menanggapi/mengajukan pertanyaan/ide (5,4\%), dan mengerjakan tes evaluasi $(10,8 \%)$.

Berikutnya adalah rekapitulasi hasil tes formatif siswa terlihat pada tabel berikut :

Tabel 4 Rekapiltulasi Hasil Tes Formatif Siswa Pada Siklus II

\begin{tabular}{lll}
\hline No & Uraian & Hasil Siklus II \\
1 & Nilai rata-rata tes formatif & 7,29 \\
2 & Jumlah siswa yang tuntas belajar & 31 \\
3 & Presentase ketuntasan belajar & 81,58 \\
\hline
\end{tabular}

Dari tabel diatas diperoleh nilai rata-rata prestasi belajar siswa adalah 7,29 dan ketuntasan belajar mencapai $81,58 \%$ atau ada 31 siswa dari 38 siswa sudah tuntas belajar. Hasil ini menunjukkan bahwa pada siklus II ini ketuntasan belajar secaraa klasikal telah mengalami peningkatan sedikit lebih baik dari siklus I. Adanya peningkatan hasil belajar siswa ini karena setelah guru menginformasikan bahaw setiap akhir pelajaran akan selalu diadakan tes sehingga pada pertemuan berikutnya siswa lebih termotivasi ntk belajar. Selain itu siswa juga sudah mulai mengerti apa yang dimaksudkan dan diinginkan guru dengan menerapkan metode pembelajarn kooperatif model TAI.

3. Refleksi

Dalam pelaksanaan kegiatan belajar diperoleh informasi dari hasil pengamatan sebagai berikut :

1. Memotivasi siswa

2. Membimbing siswa merumuskan kesimpulan/menemukan konsep

3. Pengelolaan waktu 
C. Analisis Hasil Penelitian Siklus III

1. Tahap Perencanaan

Pada tahap ini peneliti mempersiapkan perangkat pembelajaran yang terdiri dari rencana pelajaran 3 , soal tes formatif 3 dan alat-alat pengajaran yang mendukung. Selain itu juga dipersiapkan lembar observasi pengelolaan metode pembelajaran kooperatif model TAI dan lembar observasi aktifitas guru dan siswa.

\section{Tahap Kegiatan dan Pengamatan}

Pelaksanaan kegiatan belajar mengajar untuk siklus III dilaksanakan pada tanggal 26 Pebruari 2018 di kelas III dengan jumlah siswa 38 siswa. Pelaksanaan metode pembelajaran kooperatif model TAI melalui tahapan sebagai berikut: (1) Pelaksanaan pembelajaran, (2) Diskusi kelompok, (3) Tes, (4) Penghargaan kelompok, (5) Menentukan nilai individual dan kelompok. Dalam hal ini peneliti bertindak sebagai pengajar, sedangkan yang bertindak sebagai pengamat adalah seorang guru Kelas III Adapun proses belajar mengajar mengacu pada rencana pelajaran dengan memperhatikan revisi pada siklus II, sehingga kesalahan atau kekurangan pada siklus II tidak terulang lagi pada siklus III. Pengamatan (observasi) dilaksanakan bersamaan dengan pelaksanaan belajar mengajar.

Pada akhir proses belajar mengajar siswa diberi tes formatif III dengan tujuan untuk mengetahui tingkat keberhasilan siswa dalam proses belajar mengajar yang telah dilakukan. Instrument yang digunakan adalah tes formatif III dengan tujuan untuk mengetahui tingkat keberhasilan siswa dalam proses belajar mengajar yang telah dilakukan. Instrument yang digunakan adalah tes formatif III. Adapun data hasil penelitian pada siklus III adalah sebagai berikut :

\section{Tabel 5 Pengelolaan Pembelajaran Pada Siklus III}

\begin{tabular}{|c|c|c|}
\hline NO & Aspek yang diamati & Nilai \\
\hline & Pengamatan KBM & \\
\hline & A Pendahuluan & \\
\hline & 1. Memotivasi siswa & 3 \\
\hline 1 & 2. Menyampaikan tujuan pembelajaran & 4 \\
\hline 1 & $\begin{array}{l}\text { 3. Menghubungkan dengan pelajaran } \\
\text { sebelumnya }\end{array}$ & 4 \\
\hline & $\begin{array}{l}\text { 4. Mengatur siswa dalam kelompok- } \\
\text { kelompok belajar }\end{array}$ & 4 \\
\hline & B. Kegiatan inti & 4 \\
\hline & 1. Mempresentasikan langkah-langkah & 4 \\
\hline & metode pembelajaran kooperatif & 4 \\
\hline & 2. Membimbing siswa melakukan kegiatan & \\
\hline & 3. Melatih keterampilan kooperatif & 3,5 \\
\hline & 4. Mengawasi setiap kelompok secara & \\
\hline
\end{tabular}




\begin{tabular}{llc}
\hline & bergiliran & 3 \\
& 5. Memberikan bantuan kepada kelompok & \\
yang mengalami kesulitan & \\
& C Penutup \\
3 & 1. Membimbing siswa membuat rangkuman & 4 \\
& 2. Memberikan evaluasi \\
4 & Pengelolaan Waktu & 4 \\
& Antusiasme Kelas \\
5 & 1. Siswa antusias & 3 \\
& 2. Guru antisias JUMLAH & 4 \\
& & 4 \\
\hline
\end{tabular}

Dari tabel di atas, dapat dilihat aspek-aspek yang diamati pada kegiatan belajar mengajar (siklus III) yang dilaksanakan oleh guru dengan menerapkan metode pembelajaran kooperatif model TAI mendapatkan penilaian cukup baik dari pengamat adalah memotivasi siswa, membimbing siswa merumuskan kesimpulan/menemukan konsep, dan pengelolaan waktu.

Penyempurnaan aspek-aspek diatas dalam menerapkan metode pembelajaran kooperatif model TAI diharapkan dapat berhasil semaksimal mungkin.

Berdasarkan hasil observasi tampak bahaw aktivitas guru yang paling dominan pada siklus III adalah membimbing dan mengamati siswa dalam menemukan konsep yaitu $22,6 \%$, sedangkan aktivitas menjelaskan materi yang sulit dan memberi umpan balik/evaluasi/tanya jawab menurun masing-masing sebesar (10\%), dan (11,7\%). Aktivitas lain yang mengalami peningkatan adalah mengkaitkan dengan pelajaran sebelumnya (10\%), menyampiakan materi/strategi /langkah-langkah (13,3\%), meminta siswa menyajikan dan mendiskusikan hasil kegiatan (10\%), dan membimbing siswa merangkum pelajaran (10\%). Adapun aktivitas ynag tidak menglami perubahan adalah menyampaikan tujuan $(6,7 \%)$ dan memotivasi siswa $(6,7 \%)$.

Sedangkan untuk aktivitas siswa yang paling dominan pada siklus III adalah bekerja dengan sesama anggota kelompok yaitu (22,1\%) dan mendengarkan/memperhatikan penjelasan guru (20,8\%), aktivitas yang mengalami peningkatan adalah membaca buku siswa $(13,1 \%)$ dan diskusi antar siswa/antara siswa dengan guru (15,0\%). Sedangkan aktivitas yang lainnya mengalami penurunan.

Berikutnya adalah rekapitukasi hasil tes formatif siswa seperti terlihat pada tabel berikut. 


\section{Tabel 6 Rekapiltulasi Hasil Tes Formatif Siswa Pada Siklus III}

\begin{tabular}{lll}
\hline No & Uraian & Hasil Siklus III \\
& & \\
1 & Nilai rata-rata tes formatif & 7,97 \\
2 & Jumlah siswa yang tuntas belajar & 36 \\
3 & Presentase ketuntasan belajar & 94,74 \\
& & \\
\hline
\end{tabular}

Berdasarkan tabel di atas diperoleh nilai rata-rata tes formatif sebesar 7,97 dan dari 38 siswa yang telah tuntas sebanyak 36 siswa dan 2 siswa belum mencapai ketuntasan belajar. Maka secara klasikal ketuntasan belajar yang telah tercapai sebesar 94,74\% (termasuk kategori tuntas). Hasil pada siklus III ini mengalami peningkatan lebih baik dari siklus II. Adanya peningkatan hasil belajar pada siklus III ini di pengaruhi oleh adanya peningkatan kemampuan guru dalam menerapkan metode pembelajaran kooperatif moel TAl sehingga siswa menjadi lebih terbiasa dengan pembelajaran seperti ini sehingga siswa lebih mudah dalam memahami materi yang telah diberikan.

\section{Refleksi}

Pada tahap ini akan dikaji apa yang telah terlaksana dengan baik maupun yang masih kurang baik dalam proses belajar mengajar dengan penerapan metode pembelajaran kooperatif model TAI. Dari data-data yang telah diperoleh dapat diuraikan sebagi berikut :

> Selama proses belajar mengajar guru telah mekasanakan semua pembeljaran dengan baik. Meskipun ada beberapa aspk yang belum sempurna, tetapi presentase pelaksanaanya untuk masing-masing aspek cukup besar.

$>$ Berdasarkan data hasil pengamatan diketahui bahwa siswa aktif selama proses belajar mengajar berlangsung

$>$ Kekurangan pada siklus-siklus sebeelumnya sudah mengalami perbaikan dan peningkatan sehingga menjadi lebih baik.

> Hasil belajar siswa paa siklus III mencapai ketuntasan.

Melalui hasil penelitian ini menunjukkan bahawa metode pembelajran kooperatif model TAI memiliki dampak positif dalam meningkatkan prestasi belajar siswa. Hal ini dapat dilihat dari semakin mantapnya pemahaman siswa terhadap materi yang 
disampaikan guru (ketuntasanbelajar meningkat dari siklus I, II, dan III) yaitu masingmasing 68,2\%, 81,58\% dan 94,74\%. Pada siklus III kketuntasan blajr siswa secaraa klasikal telkah tercapai. Sedangakn kelompok yang mendapatkan penghargaan adalah kelompok I dengan nilai kelompok tertinggi sebesar 6,17.

\section{Kesimpulan}

Berdasarkan hasil penelitian yang telah dipaparkan selama tiga siklus, hasil seluruh pembahasan serta analisis yang telah dilakukan dapat disimpulkan sebagai berikut :

1. Metode pembelajaran kooperatif model Team Assisted Individualization dapat meningkatkan kualitas pembelajaran IPS.

2. Metode pembelajaran kooperatif model Team Assisted Individualization memiliki dampak positif dalam meningkatkan prestasi belajar siswa yang ditandai dengan peningkatan ketuntasan belajar siswa dalam setiap siklus, yaitu siklus I $(68,42 \%)$, siklus II (81,58\%), siklus III (94,74\%).

3. Metode pembelajaran kooperatif model Team Assisted Individualization dapat menjadikan siswa merasa dirinya mendapat perhatian dan kesempatan untuk menyampaikan pendapat, gagasan, ide, dan pertanyaan.

4. Siswa dapat bekerja secara mandiri maupun kelompok, serta mampu mempertanggung jawabkan tugas individu maupun kelompok.

5. Penerapan metode pembelajaran kooperatif model Team Assisted Individualization mempunyai pengaruh positif, yaitu dapat meningkatkan motivasi belajar siswa. 


\section{Referensi}

Arikunto, Suharsimi. 2001.Dasar-dasar Evaluasi Pendidikan. Jakarta: Bumi Aksara

Azhar, Lalu Muhammad. 1993. Proses Belajar Mengajar Pendidikan. Jakarta: Usaha Nasional.

Depdiknas, 2001 Pedoman Tehnis Pelaksanaan Classroom Action Research.

Djamarah,Syaiful Bahri. 2002. Strategi Belajar Mengajar. Jakarta: Rineksa Putra..

Hadi, Sutrisno. 1982. metodologi research, jilid l.yogayakarta: yp. Fak. Psikologi UGM.

Margono. 1997. Metodologi Penelitian Pendidikan. Jakarta: Rineksa Cipta.

Nur, Moh. 2001. Pemotivasian Siswa Untuk Belajar. Surabaya. University Press.

Universitas Negeri Srabaya.

Nur, Muhammad. 1996. Pembelajaran Kooperatif. Surabaya University Negeri.

Rustiyah, N.K.1991. Strategi Belajar Mengajar. Jakarta Bina Aksara.

Sardiman, A.M. 1996. Interaksi dan Motivasi Belajar Mengajar. Jakarta: Bina Aksara.

Suryosubroto, B. 1997. Proses Belajar Mengajar di Sekolah. Jakarta: PT. Rineksa Cipta..

Sutrisno, Tri. 2019. Pengaruh Pembelajaran Berbasis Masalah (Problem Based Learning)

Terhadap Kemampuan Berpikir Kritis Siswa pada Mata Pelajaran PKn Kelas VI di SDN Kota Sumenep. ELSE (Elementary School Education Journal): Jurnal

Pendidikan dan Pembelajaran Sekolah Dasar. Volume 3 Jilid 2. Hal. 98-110

Sutrisno, Tri. 2017. Merekonstruksi Kurikulum Berbasis Karakter di Sekolah Dasar. Alpen:

Jurnal Pendidikan dasar Vol 1 Jilid 1

Usman, Moh. Uzer. 2001. Menjadi Guru Profesional. Bandung: Remaja Rosdakarya.

Wiraatmadja. R 2006. Metode Penelitian Kelas, Bandung. Remaja Rosdakarya.

Jakarta 
Tri Sutrisno 